\title{
US government and utilities revive California solar project
}

Washington. The US Department of Energy this week gave the go-ahead for a \$39million project to rebuild the core of one of the world's largest solar power plants with the goal of generating commercial quantities of electricity by 1998 .

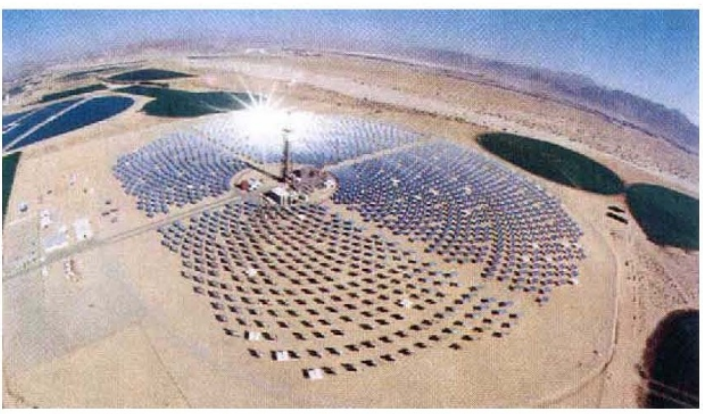

Going with the flow in California

The Solar Two project at Barstow, California, is a successor to a $10 \mathrm{MW}$ power plant that ceased operations in 1988 . Combined with the sharp increase in solar energy research proposed by US President Bill Clinton for fiscal year 1994, which begins on 1 October, the new agreement between the department and an industrial consortium is a powerful symbol of revived federal interest in renewable energy research.

The original demonstrator at Barstow used arrays of mirrors to focus the sun's rays on a central 'power tower' containing steam that was heated directly to generate electricity. This approach was abandoned after five years because the tower's output was erratic, changing when clouds passed overhead, for example.

Now the moth-balled site is to be revived with extra mirrors or heliostats, as solar researchers call them - and an energy cycle that will heat molten nitrate salt to $565^{\circ} \mathrm{C}$ and store it to generate a steady flow of steam for the existing turbo-generators.

The use of the molten salt cycle has been proved on a smaller scale at the department's Sandia National Laboratory at Albuquerque, New Mexico, which has already spent $\$ 30$ million. Significant technologies under development there includes improved stretched-membrane heliostats and pumps and valves to handle the molten salt.

The department will provide $\$ 19.5$ mil-

\section{Framework budget finds its level}

Strasbourg. The council of research ministers for the European Communities (EC) today (29 April) will discuss a proposed budget for the fourth Framework programme that matches what member countries have said they can afford.

The budget proposed last week by EC research minister Antonio Ruberti for Europe-wide research requests ECU13.1 billion (US $\$ 15.8$ billion) over the next four years. It is the maximum acceptable level, at 1993 prices, agreed to by the council of ministers and, if accepted, would represent 4 per cent of the EC's total budget. Ruberti's predecessor, Filippo Pandolfi, had asked for ECU14.7 billion, which the ministers rejected as too expensive at their last meeting in December. The current Framework programme has a budget of ECU6.6 billion.

The expansion of the programme reflects the EC's commitment to research and to the mobility of research personnel. It includes for the first time a modest amount of money for social science research, and emphasizes closer ties to international research laboratories such as CERN, the European Laboratory for Particle Physics in Geneva, and EMBL, the European Molecular Biology
Laboratory in Heidelberg, as well as closer cooperation with national research organizations.

In particular, the Framework budget is divided into seven categories: information and communications technologies, 36 per cent; energy, 23 per cent; industrial technology, 16.5 per cent; life sciences, 12 per cent; environmental research, 9 per cent; a European transportation policy, 2.5 per cent; and socio-economic research, 1 per cent.

The European Commission, which is responsible for formulating the proposal in line with the views of the council of ministers, was criticized for the repeated delays in the adoption of the third Framework programme and hopes to stick to the intricate timetable for approval of the new programme, which must be accepted at three levels. The council of research ministers is expected to reach a decision by the beginning of June. At the same time, the European Parliament is considering the document and expected to finish its work by the beginning of July. The goal is a political agreement in July between the council, commission and parliament but acceptance rests with ratification this summer of the Maastricht Treaty.

Alison Abbott lion over the next three years to build Solar Two, a sum to be matched by the South California Edison Company and ten other industrial partners. Construction will begin in the summer of 1994 for operations in 1996 intended to prove the technology can be used in commercial $100 \mathrm{MW}$ solar power stations.

A proposed budget increase of $\$ 70$ million for renewable energy, to a total of $\$ 327$ million, is spread evenly across photovoltaic research, thermal solar energy work (including Solar Two), biofuels and wind power. The department also intends to spend $\$ 16$ million to find commercial applications for existing renewable technologies.

The strongest opposition is likely to come from supporters of nuclear power, which was cut sharply in the Clinton budget. But advocates of renewable energy point out that the new budget still leaves the field far behind where it stood more than a decade ago, when President Jimmy Carter spent as much as $\$ 800$ million a year on renewable research.

Colin Macilwain

\section{NEWS IN BRIEF}

Washington. The US National Aeronautics and Space Administration (NASA) has expanded the length and scope of its mission in December to cope with the growing list of faults on the Hubble Space Telescope. The new schedule calls for five spacewalks rather than the three originally planned for a mission lasting 11 days rather than eight. Two pairs of astronauts from the mission's seven-member crew will alternately perform the spacewalks, a record number that may be further increased to seven. NASA says that the extension of the mission would not add substantially to the cost.

The repairs to be carried out include the replacement of gyros, solar arrays and cameras and the installation of a device to correct the optics of the troubled telescope, launched in April 1990.

C.M.

Paris. France's Genetic Engineering Commission last week approved as safe the country's first gene therapy trial for cystic fibrosis. The decision opens the way for the trial to begin this autumn pending approval from the French drug agency and the local ethics committee. The trial, submitted by Transgène, a French biotechnology company, and supported by the French Cystic Fibrosis Association, will test the feasibility and tolerance of aerosol administration of the CFTR gene. Gabriel Bellon of Lyon will carry out the trials on several adult volunteers. The CF-modified adenovirus vector, developed by Transgène and Michel Perricaudet of the Centre National de la Recherche Scientifique viral genetics laboratory at Villejuif, is the same as that used earlier this month by Ronald Crystal of Cornell University in New York on a 23-year-old patient in the first CF gene therapy trial.

D.B. 